\title{
Work Ethic of Butonese Women in The West Coast of Seram Island, Maluku
}

\section{Etos Kerja Perempuan Buton di Pesisir Barat Pulau Seram, Maluku}

\author{
Nur Aisa Hamid1, Dwia Aries Tina Pulubuhu², Hasbi ${ }^{3}$ \\ 1 Universitas Hasanuddin, Makassar, Indonesia. E-mail: hamidna17e@student.unhas.ac.id \\ 2 Universitas Hasanuddin, Makassar, Indonesia. E-mail: dwiatn@yahoo.com \\ 3 Universitas Hasanuddin, Makassar, Indonesia. Email: hasbifisip@unhas.ac.id
}

\begin{tabular}{l}
\hline ARTICLE INFO \\
\hline Keywords: \\
Work ethics; Butonese \\
trader women; coastal \\
community; Pajibujibu. \\
How to cite: \\
Hamid, N.A., Pulubuhu, \\
D.A.T., Hasbi. (2020). \\
Work Ethic of Butonese \\
Women in the West Coast \\
of Seram Island, Maluku. \\
ETNOSIA: Jurnal \\
Etnografi Indonesia. 5(2): \\
332 - 348. \\
DOI: \\
10.31947/etnosia.v5i2.11308
\end{tabular}

\begin{abstract}
The article aims to explain Butonese women work ethics focusing on three factors, namely the development of work ethics, the aspects, and the challenges in developing their businesses. The research is a qualitative research with case study. The study is conducted in four villages in Luhu Hoamual District and West Seram District in Maluku Province, including Temi, Tapinalo, Mangge-mangge, and Eli. The informants were the Butonese women whose professions are traders. The methods used in this research are observation, interview and library research. The data analysis was done through reduction, presentation and concluding processes. This study found that the work ethic of Butonese women is not due to a religious calling as Weber said, but as a rational choice following Coleman ideas of surviving from the nature challenges, business opportunities, and family's economic condition. In this process, two professions with different orientations were born. The pajibujibu sell their agricultural and plantation products from the west coast of Seram in Ambon city, meanwhile, the papalele sell fishery products on the west coast of Seram and the Hitu peninsula. If papalele is easy to get access to capital for business development, pajibujibu finds challenges to get it. Therefore, pajibujibu finds difficult to develop the business in compared to papalele. Nevertheless, both play important roles as actors in the economy of coastal communities.
\end{abstract}

\section{Pendahuluan}

Ambon merupakan salah satu kota dagang terkemuka di Maluku yang menarik perhatian banyak orang dari berbagai daerah di kawasan Timur Indonesia. Kota ini semakin dikenal dan masuk dalam jaringan pelayaran dan perdagangan dengan 
kedatangan bangsa Eropa pada abad keenambelas (Zuhdi et al., 2019). Di antara pedagang dari luar daerah adalah orang Buton, Sulawesi Tenggara, yang pada umumnya mengidentifikasi diri dengan Mia Bhinongko (orang Binongko), kendati mereka bukan dari Pulau Binongko, Kepulauan Tukang Besi (sekarang Kabupaten Wakatobi). Hal itu tak lepas dari faktor historis, karena orang Binongko merupakan migran awal dari Buton di Maluku terutama Kota Ambon dan Pulau Seram (Hamid, 2016). Sampai sekarang mereka berperan aktif dalam menghidupkan perekonomian kota di pasar Batu Merah dan pasar Mardika. Selain berprofesi sebagai pedagang, orang Buton di sekitar kota juga menjadi petani dan menjual hasil perkebunan mereka di pasar kota.

Berdasarkan sensus penduduk 2020 (Butar, 2020) jumlah penduduk Maluku 1,802,000 jiwa. Data tersebut tidak menampilkan kategori etnis, namun sebagai gambaran dapat dilihat pada data tahun 2009 yang menunjukan jumlah orang Buton di Provinsi Maluku sebanyak 420.023 jiwa atau 35\% dari total penduduk. Khusus di Kabupaten Seram Bagian Barat jumlahnya mencapai 94.390 jiwa dari total 157.318 jiwa atau 65 persen (Zuhdi et al., 2019). Menurut Zuhdi (2014) orang Buton di Kota Ambon pada awalnya bekerja sebagai tukang beca, penjual barang kelontong, dan hasil bumi berskala kecil. Berkat keuletannya dalam bekerja dan semangat juang pantang menyerah yang besar, orang Buton dapat meraih keberhasilan dalam berbagai bidang kehidupan. Dalam perkembangannya kini banyak pujian yang diberikan oleh orang Ambon untuk keberhasilan mereka. Orang Buton, kini menguasai perekonomian di pasar Mardika. Sehubungan dengan itu, orang Ambon menyebut mereka mungkin berlebihan yakni dikatakan seperti "Orang Cina yang pandai berdagang".

Sebelum konflik 1999, masyarakat Buton dari pesisir barat Pulau Seram ke pasar Batu Merah dan Mardika hanya untuk berbelanja bahan kebutuhan sehari-hari. Tidak banyak perempuan pesisir yang mengakses pasar, kecuali sebagian kecil yang mampu menjangkaunya. Kunjungan ke pasar tersebut menjadi sumber pengetahuan mereka mengenai dunia perdagangan. Pada saat itu, perdagangan di Batu Merah dan Mardika didominasi pedagang orang Buton dari Sulawesi Tenggara. Akibat konflik banyak pedagang Buton kembali ke daerah asalnya yang menyebabkan kekosongan aktifitas perdagangan di pasar. Kekosongan tersebut kemudian dimanfaatkan oleh perempuan pedagang Buton dari pesisir Barat Pulau Seram untuk berdagang di pasar kota yang dikategorikan atas pajibujibu dan papalele. Pajibujibu adalah pedagang hasil pertanian dari kampung ke pasar kota dan sebaliknya, sedangkan Papalele adalah pedagang ikan keliling di pesisir barat Pulau Seram dan Jazirah Laihitu, bahkan sampai di pasar kota.

Seorang perempuan dalam kebudayaan maritim Wakatobi Buton harus mampu tampil sebagai pemimpin, ketika suaminya berada di luar rumah (merantau). Dia harus mampu mengambil kebijakan, menjaga keamanan, menjaga kesejahteraan, hingga ia menjadi guru bagi anak-anaknya (Udu, 2017). Jika sebuah keluarga mengalami kesuksesan di bidang ekonomi, maka pertanyaan orang-orang Buton adalah "siapa istrinya?", karena dalam pemahaman orang-orang Buton bahwa dunia luar sangat 
dipengaruhi oleh keharmonisan di dalam keluarga. Bahkan dalam beberapa kasus terakhir, perempuan Wakatobi Buton telah mengalami keunggulan dalam dunia bisnis. Bahkan mereka juga sudah bertugas sebagai pembeli barang di Makassar, Surabaya dan Jakarta. Keterlibatan perempuan dalam aspek ekonomi pada aktifitas sebagai pedagang, khususnya jual beli, didominasi oleh perempuan pada beberapa pasar di Wakatobi. Perempuan mempunyai keunggulan dalam proses tawar-menawar pada proses jual beli seperti sabar, teliti, ulet, dan mampu memberikan pelayanan yang menarik pembeli. Berdasarkan keunggulan tersebut, maka dapat dikatakan bahwa kunci perekonomian masyarakat Wakatobi berada di tangan kaum perempuan (Udu, 2009). Dalam Tari Bawine (Bolu, 2019) digambarkan keadaan perempuan Buton saat ini yang bebas menentukan jalan hidup dan memilih hak termasuk untuk melanjutkan pendidikan kejenjang yang lebih tinggi.

Sejauh ini belum ada studi yang memfokuskan mengenai peran ekonomi perempuan Buton di Maluku khususnya Kota Ambon dan pantai barat Pulau Seram. Hasil penelitian Renyaan (2016), tentang budaya bahari mendorong orang Buton berlayar ke Pulau Seram mencari komoditas niaga terutama damar di pedalaman. Kegiatan itu menarik perhatian mereka dan kemudian mengelolah lahan pertanian, mendirikan pemukiman, dan akhirnya menetap di sana. Penduduk pantai barat Pulau Seram mayoritas dari suku Buton yang menekuni profesi petani dan nelayan. Sejarawan Gerrit Knaap menulis bahwa pada abad ke-17 orang Buton dijumpai di Maluku terutama Pulau Seram dan Ambon sebagai pekerja kasar (Hamid, 2015). Studi lain (Zuhdi et al., 2019) menemukan bahwa sebagian besar orang Buton di Kota Ambon dan sekitarnya bekerja pada sektor ekonomi seperti penghasil tanaman untuk makanan, buruh, pedagang kaki lima, kuli pasar dan bangunan, supir mobil dan tukang becak, dan pekerjaan kasar lainnya. Masuknya orang Buton terutama dari Binongko memberi berkah bagi orang Ambon, seperti pernyataan berikut "di tangan orang Buton batu keras bisa menjadi tanah yang produktif". Mereka menanam beberapa jenis tanaman sayur di Ambon yang hasilnya dinikmati masyarakat kota. Karena karakter yang ulet dan dapat dipercaya sehingga orang Ambon dengan suka rela memberi lahan atau meminjamkan lahannya kepada orang Buton untuk digarap. Orang Buton dikenal pandai menyesuaikan diri dan ulet. Dalam kajian Talakua (Talakua, 2018) tentang orang Buton di desa Rumah Tiga Kota Ambon bahwa orang Buton dapat dipercaya. Ketika diberikan tanah untuk berkebun, mereka mampu menjaga batas-batas tanah dari orang Rumah Tiga. Kehidupan mereka saling mengisi, masyarakat setempat memberikan mereka lahan untuk bertani dan sebagai balasannya orang Buton bertani dapat memberikan kehidupan bagi masyarakat setempat dengan hasil pertaniannya.

Oleh karena itu, artikel ini akan menjelaskan tentang etos kerja perempuan Buton. Bagaimana peran perempuan Buton menghidupkan perekonomian keluarganya? Artikel ini akan berfokus pada: pertama, faktor-faktor yang melatari lahirnya etos kerja perempuan Buton? kedua, aspek-aspek apa yang membuat etos kerja dapat bertahan? dan ketiga, apa kendala yang dihadapi perempuan Buton untuk mengembangkan usahanya? Permasalahan tersebut dianalisa dengan pendekatan sosiologi 
menggunakan teori etos kerja Max Weber (Weber, 2009) dan teori pilihan rasional James S. Coleman (Ritzer \& Goodman, 2003).

\section{Metode}

Penelitian ini menggunakan pendekatan deskriptif kualitatif. Lokasi penelitian dilaksanakan di empat dusun yaitu Dusun Temi, Tapinalo, Mangge-mangge, dan Eli. Desa Luhu dan Desa Iha, Kecamatan Huamual, Kabupaten Seram Bagian Barat, Provinsi Maluku. Pengumpulan datanya diperoleh melalui observasi, wawancara, dan studi pustaka. Observasi dilakukan untuk melihat langsung aktifitas perdagangan pajibujibu dan papalele di daerah pesisir dan pasar di kota Ambon, khususnya Batu Merah dan Mardika. Wawancara mendalam menggunakan bahasa lokal seputar kegiatan Pajibujibu mulai dari proses pencarian barang dagangan di kampung, penyiapan barang untuk dibawa ke pasar kota, sampai penjualannya di Pasar Batu Merah dan Pasar Mardika. Serta proses para Papalele yang menyiapkan keperluan anak dan suaminya di rumah sebelum pergi berdagang dan saat menjual ikan di pesisir. Studi pustaka dengan penelusuran literatur berupa artikel dan buku.

Informan dalam penelitian ini perempuan Buton berjumlah 13 orang yang telah berkeluarga dan berprofesi sebagai pedagang pajibujibu dan papalele. Informan dipilih dengan metode purposive sampling. Pedagang pajibujibu 5 orang berasal dari Dusun Temi dan Tapinalo yang berdagang di Kota Ambon. Sedangkan pedagang papalele 8 orang dari Dusun Mangge-mangge dan Eli yang berjualan di pesisir barat Pulau Seram dan Jazirah Laihitu.

Tabel 1. Daftar informan

\begin{tabular}{|c|c|c|c|c|c|}
\hline No & $\begin{array}{c}\text { Nama } \\
\text { Informan }\end{array}$ & $\begin{array}{l}\text { Lamanya } \\
\text { Berdagang }\end{array}$ & Pekerjaan & Lokasi Berdagang & Jam Kerja \\
\hline 1 & Wa Asiah & 20 tahun & $\begin{array}{c}\text { Mantan } \\
\text { Pajibujibu }\end{array}$ & & - \\
\hline 2 & Ina Udu & 30 tahun & \multirow{4}{*}{ Pajibujibu } & \multirow{4}{*}{$\begin{array}{l}\text { Pasar Batu Merah dan Pasar } \\
\text { Mardika, kota Ambon. }\end{array}$} & \multirow{4}{*}{$\begin{array}{c}\text { Setiap } \\
\text { Minggu 2-3 } \\
\text { hari dari jam } \\
\text { 12:00 - 7:00 }\end{array}$} \\
\hline 3 & Nene Elo & 21 tahun & & & \\
\hline 4 & Wa Sami & 10 tahun & & & \\
\hline 5 & Wa Siti & 8 tahun & & & \\
\hline 6 & Wa Nurjana & 20 tahun & $\begin{array}{l}\text { Mantan } \\
\text { Papalele }\end{array}$ & - & - \\
\hline 7 & Wa Hamida & 10 tahun & \multirow{7}{*}{ Papalele } & \multirow{7}{*}{$\begin{array}{c}\text { Daerah pesisir Barat Pulau } \\
\text { Seram (Temi, Limboro, Lirang, } \\
\text { Nasiri, Talaga, Hatawano, } \\
\text { Asamjawa, Amoholu, Batu } \\
\text { Lubang, Air Papaya) dan } \\
\text { Negeri Lima, Seit, Wakal, } \\
\text { Mamua, Waitomu (Pesisir } \\
\text { Jazirah Laihitu, Kab. Maluku } \\
\text { Tengah) }\end{array}$} & \multirow{7}{*}{$\begin{array}{c}\text { Setiap Hari } \\
\text { dari jam 7:30 } \\
\quad-16: 00\end{array}$} \\
\hline 8 & Wa Abu & 15 tahun & & & \\
\hline 9 & Wa Onya & 10 tahun & & & \\
\hline 10 & Nene Ou & 16 tahun & & & \\
\hline 11 & Wa Ija & 2 tahun & & & \\
\hline 12 & Wa Sri & 7 tahun & & & \\
\hline 13 & Wa Riyana & 1 tahun & & & \\
\hline
\end{tabular}




\section{Hasil Penelitian dan Pembahasan}

\section{Lahirnya Etos Kerja}

Anoraga (2001) mengungkapkan bahwa salah satu faktor etos kerja dipengaruhi oleh faktor lingkungan. Kondisi lingkungan yang mendukung mempengaruhi manusia yang berada di dalamnya melakukan usaha untuk dapat mengelola dan mengambil manfaat, bahkan dapat mengundang pendatang untuk turut mencari penghidupan di lingkungan tersebut. Ketika menentukan pilihan, seseorang harus berpikir secara rasional mengenai apa yang harus dilakukan dan menghasilkan nilai lebih dari tindakannya. Dalam teori pilihan rasional oleh Coleman (Ritzer \& Goodman, 2003), mengatakan bahwa tindakan perseorangan mengarah kepada suatu tujuan dan tujuan itu (disertai tindakan) ditentukan oleh nilai atau pilihan. Tentunya dari sebuah tindakan tersebut seseorang dapat menemukan peluang usaha agar dapat keluar atau mengatasi tantangan yang dihadapi.

Pantai Barat Pulau Seram, khususnya pada sembilanbelas dusun (Ulatu, Tapinalu, Erang, Temi, Limboro, Lirang, Nasiri, Kambelu, Talaga, Mangge-mangge, Losi, Asam Jawa, Amoholu, Hatawano, Batu Lubang, Eli Kecil/Jaya, Eli Tanah Merah, Eli Besar, Air Papaya) dalam wilayah administratif Desa Luhu dan Desa Iha, Kecamatan Huamual, masyarakatnya hidup dari hasil pertanian dan perikanan. Dari sembilanbelas dusun tersebut, diantaranya memiliki tanah yang subur yaitu dusun Temi dan dusun Tapinalu (Desa Luhu), sedangkan diantara daerah yang memiliki tanah kurang subur ialah dusun Mangge-mangge dan dusun Eli (Desa Luhu dan Iha). Kondisi ini membuat mereka memilih pekerjaan sesuai kebutuhannya.

Masyarakat yang mendiami daerah yang subur mengembangkan usaha pertanian. Terdapat dua jenis tanaman yang mereka tanam, yakni tanaman jangka pendek dan tanaman jangka panjang. Jenis pertama berupa ubi kayu yang difermentasi menjadi gepeng, tanaman rempah-rempah (sere, kunyit, lengkuas, jahe, cabai, tembulawak, dll) untuk bumbu masakan, dan sayur-sayuran. Sedangkan jenis kedua adalah cengkeh dan pala. Selain untuk kebutuhan sehari-hari, hasil tanaman mereka juga untuk dijual. Tanaman jangka pendek sangat membantu kebutuhan sehari-hari sebab tidak butuh waktu lama untuk panen. Sedangkan tanaman jangka panjang untuk simpanan, karena sekali panen dapat memenuhi kebutuhan hidup, termasuk jika ada untuk membayar hutang. Hasil pertanian dijual di Kota Ambon terutama pasar Batu Merah dan pasar Mardika melalui pedagang pajibujibu dari daerah tersebut. Berdagang sebagai pajibujibu sangat membantu ekonomi keluarga terutama biaya anak sekolah dan kebutuhan sehar-hari. Hasil panen cengkeh, berbuah tiga tahun sekali, tidak cukup menutupi kebutuhan keluarga. Maka berdagang menjadi solusi untuk memenuhi kebutuhan ekonomi keluarga.

Masyarakat yang mendiami daerah kurang subur mengembangkan usaha perikanan. Kehidupan masyarakat di kampung Eli dan Mangge-mangge, sebagian besar bergantung pada usaha perikanan rakyat menggunakan jareng bobo (transportasi penangkap ikan). Para lelaki biasanya mencari ikan di laut dengan transportasi tersebut, sedangkan perempuannya menunggu suami atau anak atau saudara laki- 
lakinya untuk menjajakan hasil tangkapan mereka. Jenis ikan yang biasa dijual oleh papalele adalah ikan layang (momar), ikan tongkol (komu), dan ikan kembung (palala). Nene Ou dari Dusun Eli mengungkapkan bahwa kalau bukan bekerja sebagai papalele maka tidak ada yang bisa diharapkan untuk menunjang kebutuhan keluarga. Usaha tersebut mengingatkan pada ungkapan dari Franklin (dalam Weber 2006) bahwa "ingatlah waktu adalah uang"!. Begitupun yang dilakukan perempuan Buton. Menurutnya "setiap waktu yang berlalu ada uang yang harus dijemput dipembeli". Sebagian besar kehidupan mereka ditopang oleh sektor perikanan rakyat bahkan menjadi mata pencaharian utama bagi penduduk.

Lahirnya etos kerja juga tak lepas dari tuntutan kebutuhan ekonomi keluarga. Desi yang berusia enam tahun, anak seorang papalele. Setiap kali ibunya pergi, dia sering menangis. Ibunya tak perlu berupaya untuk membujuk agar diberikan izin, bahkan justru langsung meninggalkannya. Pasalnya hal itu sudah biasa dilakukan, dan bila anaknya sudah lelah maka pada akhirnya akan diam juga. Apa yang dilakukan oleh informan Wa Nurjana adalah untuk memenuhi kebutuhan ekonomi keluarga dan anaknya menjadi sumber motivasi untuk terus bekerja. Keputusan yang diambil, berdasarkan kondisi yang dihadapi sekarang dalam keluarga, yaitu memenuhi kebutuhan sehari-hari dan biaya anak sekolah. Maka dari itu untuk mewujudkannya mereka harus mempunyai etos kerja agar dapat terpenuhi. Bila ingin hidup secukupnya maka bekerjalah secukupnya, tapi bila ingin hidup lebih maka bekerjalah lebih keras untuk mendapatkan hasil lebih. Hidup secukupnya atau lebih! Bila perempuan Buton hidup secukupnya maka tidak perlu bekerja keras untuk membantu suaminya memenuhi kebutuhan keluarga. Kebutuhan sehari-hari dapat terpenuhi dari hasil kerja suaminya baik sebagai petani ataupun nelayan. Kebutuhan lain seperti biaya sekolah anak-anak mereka tidak cukup dengan pendapatan tersebut. Karena itu dia harus terlibat mencari nafkah untuk tambahan pendapatan keluarga terutama biaya studi supaya anak-anaknya dapat mengenyam pendidikan sampai perguruan tinggi (kampus).

Acapkali terucap kalimat dari informan Wa Siti bahwa "cukup kami (orang tua) yang bersusah payah bekerja dengan tenaga fisik (banting tulang), tapi jangan lagi dialami anak-anak kami. Mereka cukup gunakan pena dan ilmu yang diperoleh di bangku sekolah untuk memenuhi kebutuhan hidupnya nanti". Kendati demikian masih juga ada anak-anak yang bekerja, sebagai petani atau nelayan, untuk menyangga ekonomi keluarga. Bagi sebagian orang tua, bahwa dengan pendidikan yang tinggi maka anakanaknya kelak mendapatkan pekerjaan terbaik bagi masa depannya. Prinsip kebersamaan (Hamid, 2015) sebagai implementasi nilai budaya sabangka asarope atau teman setujuan melahirkan etos kerja. Kesatuan kata dan langkah dalam usaha pelayaran dan perdagangan menjadi unsur utama tradisi bahari orang Buton (Hamid, 2011; Tahara, 2016). Apapun yang terjadi mereka tetap bersama-sama dari berangkat berdagang sampai kembali kekampung. Hal itu juga terdapat dalam aktifitas pedagang pajibujibu maupun papalele.

Dalam perdagangan pajibujibu pembelian barang masih dalam lingkup keluarganya dan setelah itu ke petani lainnya. Pada lingkup keluarga harga barang masih bisa 
ditunda pembayarannya, nanti setelah pajibujibu kembali dari pasar kota baru dibayar. Sedangkan ke petani lain harus langsung dibayar saat barang telah dibawa kerumah pajibujibu atau pembayar bisa dilakukan dengan membelikan barang seperti sabun dari kota untuk petani. Biasanya mereka ke pasar kota bersama pajibujibu lainnya sekitar 3 orang. Saat berjualan di pasar masing-masing menjual barangnya dan saling menunggu jika akan kembali ke kampung. Pajibujibu lebih senang bertransaksi dengan pedagang orang Buton yang ada di Pasar Batu Merah dan pasar Mardika. Karena menurut mereka pedagang orang Buton lebih bisa dipercaya yang tentunya telah dikenalnya. Berikut ungkapan dari Nene Elo bahwa:

Inda melapaiya'i langgananuwa'i sa'ataa abundo doweuwa'i ciaepo ataliku kasiapusiau. 'ato abundo cuke hawite kabadawu I Mardikailo asala mia Buton ukana jari inda ka jujuru, doeu ane ahacu'iwu (Rp 100.000) kakumbu-kumbue ane rekee cuke humbug. Mae mia Limboro mowine Risman, pande alauka barau. Pande pombae makanya ambel beta pung barang lai hanggai dia bagus. Kapapa'aso I Mardika. Pombau gilagi anunde nantalea cuminte I tampa ala hargaa barami, pombae moapa labu ciamoapa. Sedangka ciaepoka amalae ciamoapa papadaikita, impa cukaminte lae, topoikoikoni, hadaike inda pombae ombe asala cumalae wite barau! Ombe ane cubundoaho maka pococaho harga maka amalae wite.

Artinya

Langganan saya baik kalau sudah datang uang barang sebelum pulang kampung sudah disiapkan. Kalau datang ditempatnya langsung kasi di pasar Mardika, kebetulan orang Buton juga jadi jujur. Uang saya kalau Rp. 100.000 digulung-gulung kalau dihitung pasti cukup. Orang Limboro juga yang istrinya orang Buton berdagang di pasar Mardika juga ambil barang dagangan dari saya. Biasa saya bilang ambil barang dari saya juga sebab bagus kualitasnya. Jika uangnya belum ada saat mengambil barang, maka saya diminta kembali besoknya ditempat jualannya. Bahkan walaupun belum saya ambil tidak apaapa, soalnya sama-sama kita orang Buton, mau kemana sudah saling mengenal. Sering saya bilang dia usahakan selalu ambil barang dari saya!. Dia jawab iya kalau sudah datang dan cocok harga pasti ambil.

Sedangkan dalam perdagangan papalele mereka berangkat selalu berkelompok (10-20 orang) dengan menggunakan satu kendaraan laut (pentura/jonson). Sasaran penjualan mereka di kampung-kampung yang berpenduduk orang Buton di pesisir Barat Pulau Seram dan pesisir Hitu. Ikan mereka ambil dari jareng yang ada di kampungnya, tentunya antara pemiliki ikan dengan papalele saling mengenal. Sebelum turun dari pentura untuk berjualan, terlebih dahulu mereka melakukan kesepakatan harga jual ikan. Jadi saat menjual ikan harganya sama semua papalele. Bila salah satu papalele ikannya sudah terjual habis dan temannya belum terjual habis, maka mereka akan menunggunya di pantai atau pentura sampai ikannya laku terjual semua. Bahkan jika tidak merasa capek berkeliling mereka membantu temannya menjualkan ikannya. Sebagaimana pernyataan dari Wa Sri bahwa:

Topoaantagi cukee Ibodi, humbu sawutae sami cukee kata tobale. Kadang topohahamba uka ane mela uka jiwano hamba kita uka. Hawali ane ngareno uka, ngare agaa cuke acutau kita bara isanto cukee daneeuka Ibodi agaa ngare uka. Hadaike ane tohangka to ailea (tolidmae ina posanau) hamba upolae hamba kita mouka cukee kan topokoikoni. 


\section{Artinya}

Saling menunggu di jonson, cukup semua baru pulang. Kadang saling membantu kalau lagi baik, kadang juga tidak dibantu walaupun ikan masih ada soalnya cape mungkin. Tapi biasanya kami berangkat dalam satu kendaraan masih ada hubungan keluarga (sepupu sama tante) bantu saya dulu pasti dibantu sebab sudah saling mengenal.

Biasanya mereka berangkat dalam satu kendaraan itu masih ada ikatan keluarga seperti tante dan sepupunya. Dalam kelompok ini mereka lebih mudah meminta bantuan untuk dijualkan ikannya jika belum terjual habis. Ikatan emosional antara sesama pedagang, pedagang dengan pemilik barang, dan pedagang dengan pembeli sangat berpengaruh dalam perdagangan mereka.

\section{Aspek-aspek Etos Kerja}

Menurut Weber (2009) antara agama dan kerja saling menopang dan bergerak dalam arah yang sama, sehingga melahirkan semangat kapitalisme modern. Sukses kerja dalam agama menjadi pembuktian diri sebagai manusia pilihan Tuhan. Sedangkan sukses kerja dalam masyarakat sebagai pembuktian mempertahankan diri secara sosial. Santos Thomas Aquino melihat kerja sebagai suatu keharusan demi kelanjutan hidup. Sedangkan Calvinisme terutama sekte Puritanisme melihat kerja sebagai panggilan (Abdullah, 1986). Jadi kerja tidaklah sekedar pemenuhan keperluan, tetapi suatu tugas yang suci. Sikap hidup keagamaan yang diinginkan oleh Calvinisme kata Weber ialah askes duniawi yaitu intensifikasi pengabdian agama yang dijalankan dalam kegairahan kerja, sebagai gambaran dan pernyataan dari manusia yang terpilih. Dalam kerangka pemikiran teologis bahwa semangat kapitalisme bersandar pada cita ketekunan, hemat, berperhitungan, rasional, dan sanggup menahan diri, menemukan pasangannya. Sukses hidup yang dihasilkan oleh kerja keras dari manusia dianggap sebagai orang pilihanTuhan.

Perempuan Buton bekerja semata-mata untuk kelanjutan hidup, jadi tidak ada hubungannya dengan panggilan agama. Kondisi alam dan kebutuhan ekonomi membuat perempuan Buton mengambil keputusan bekerja guna membantu suami, atau sebagai single parent, dalam memenuhi kebutuhan keluarga. Hal itu melahirkan etos kerja mereka. Beberapa aspek dari semangat kapitalisme diantaranya yaitu ketekunan ada dalam (kesungguhan, optimis, dan kemandirian), dan rasional ada dalam (kesadaran dan kejujuran) Nampak dalam aktifitas Pajibujibu dan Papalele. Semangat kerja keras berdampak terhadap perbaikan kehidupan ekonomi. Dengan kerja keras serta hidup sederhana menjadikan hidup mereka lebih baik.

\section{$>$ Kesadaran}

Etos kerja dalam (Sukardewi et al., 2013) ialah sikap yang muncul atas kehendak dan kesadaran sendiri yang didasari oleh sistem orientasi nilai budaya terhadap kerja. Kesadaran atas situasi yang dihadapi dengan kondisi alam (tanah) yang berbeda antara subur dan kurang subur. Serta tuntutan pemenuhan kebutuhan ekonomi keluarga, menghendaki keterlibatan para perempuan di pesisir harus 
bekerja dalam memenuhi kebutuhan ekonomi keluarganya dan bahkan karena statusnya sebagai single parent.

Mereka yang tinggal di daerah kurang subur tanahnya hanya bisa memanfaatkan hasil laut yaitu ikan untuk dijual dari tangkapan Jareng Bobo (transportasi penangkap ikan). Dimana para suami atau anak laki-lakinya atau saudara lakilakinya ikut serta dalam penangkapan tersebut. Para perempuan bekerja sebagai pedagang Papalele dalam menunjang kebutuhan sehari-hari keluarganya. Menurut penduduk setempat, selain ikan tidak ada yang bisa diharapkan untuk berpenghasilan bagi para perempuannya. Sedangkan bagi mereka yang mendiami daerah yang memiliki tanah subur memiliki pilihan bekerja sebagai petani atau sebagai pedagang Pajibujibu dari hasil pertaniannya dalam menunjang kebutuhan sehari-harinya dan kebutuhan anak sekolahnya.

Bahkan resiko dari tindakannya telah mereka pertimbangkan seperti meninggalkan suami dan anak-anak yang seharusnya masih dalam pengasuhannya selama pergi Pajibujibu atau Papalele. Anak-anaknya harus bisa mengurus diri sendiri saat mereka pergi berdagang. Biasanya anaknya ditinggalkan di rumah bersama teman-temannya bermain atau dititipkan ke tetangganya hanya untuk sesekali dilihat bahwa sang anak baik-baik saja. Bilamana sang anak lapar dan tidak mendapati lauk seperti ikan untuk dimakan bersama Kasuami atau nasi, mereka akan pergi ke warung berutang sarimi untuk lauknya. Setelah ibunya pulang dari berdagang, mereka beritahu kalau mereka berutang di warung agar ibunya membayar sarimi tersebut. Hal tersebut sering berulang saat anak-anak Papalele Wa Onya lapar dan itu tidak mengapa. Berdagang bagi perempuan pesisir semata-mata untuk keluarganya dan sangat membantu pemenuhan kebutuhan ekonominya. Senada dengan Pajibujibu Nene Elo, bila awalnya berdagang untuk biaya pendidikan anak-anaknya. Tidak ada pilihan selain meninggalkan anaknya bersama ayahnya atau keluarga yang lainnya termasuk tetangganya. Saat itu anaknya masih SD dan anak bungsu berumur 3 tahun. Pernah suatu hari si bungsu menangis di belakang rumah mereka dan kejadian tersebut tidak diketahui oleh ayahnya. Beruntung si anak dilihat tetangganya, kemudian dipanggillah pulang kerumah. Saat Nene Elo pulang berdagang dari kota ia diberitahukan hal tersebut. Sekarang anak-anaknya telah berkeluarga dan Nene Elo masih berdagang sebagai Pajibujibu hanya untuk kebutuhan makan sehari-harinya saja.

$>$ Kesungguhan dan Mandiri

Tasmara (2002) melihat keinginan untuk mandiri dalam etos kerja ditandai dengan upaya individu untuk berusaha mengaktualisasikan seluruh kemampuannya dan berusaha memperoleh hasil dari usahanya sendiri tanpa menunjukkan ketergantungan pada pihak manapun. Usaha yang sungguhsungguh dan bekerja secara mandiri merupakan gambaran etos kerja perempuan Pajibujibu dan Papalele selama berdagang di pasar Kota Ambon, daerah pesisir 
Barat Pulau Seram, dan bagian Kabupaten Maluku Tengah (pesisir Leihitu) tanpa pendampingan dari suami atau keluarga lainnya.

Bukan akhir bagi mereka bila tidak mendapatkan lokasi jualan ditempat yang menjadi perebutan antara sesama Pajibujibu di pasar Batu Merah. Sebab mereka memiliki cara pemasaran barang dagangan dengan menjualnya sendiri langsung. Pada malam hari di pasar Batu Merah bagian jembatan dan siang harinya berkeliling menjualnya kepedagang yang ada di pasar Mardika. Sebagaimana yang diungkapkan oleh Pajibujibu Nene Elo dan Ina Udu “Depan jalan, tapi tempat tersebut menjadi perebutan siapa cepat dia dapat. Tempat umum soalnya, kalau tidak dapat ya nganggur sambil istirahat karena tidak jualan. Kadang sewa tempat Rp.10.000 semalam dipedagang Mama Tati, soalnya kalau malam hari mereka tidak jualan. Jadi malam hari kami yang gunakan bagian depan tempat jualan mereka. Kalau sudah datang hampir siang pemiliknya, kami pindahkan lagi barang jualan kami ke depan toko kosong. Jadi kalau sudah begitu kami keliling menjual barang dagangan tadi di Pasar Mardika".

Membutuhkan semangat lebih untuk setiap aktifitasnya, mulai dari pengambilan ikan dan saat penjualannya. Berdesak-desakkan dengan teman-teman Papalele lainnya saat mengambil ikan dari jareng dilakukan sendiri. Lengah sedikit saja pada saat berdesak-desakan, maka mereka hanya mendapatkan sedikit ikan saja. Sebagaimana yang dikatakan oleh Papalele Wa Ija "Tidak kami perempuan saja, kalau sudah singgah jareng kami naik minta untuk beli ikan mereka. Kalau pemiliknya mengiyakan langsung ambil, kalau tidak ya tidak ambil. Kecuali ada jibu-jibu yang punyak anak/suami/adik ikut jareng langsung ambil bagiannya. Kalau kami minta dulu". Setelah mereka berhasil mengumpulkan ikannya dan harganya telah ketahui. Maka langsung mereka pindahkan ikannya kendaraan laut atau biasa disebut pentura/jonson yang mengantar kedaerah pesisir tujuan penjualannya. Mereka menjual ikannya dengan cara dikeku bahasa daerah setempat (baskom besar yang ditaruh diatas kepala) sambil berkeliling dibeberapa kampung pesisir.

$>$ Kejujuran

Kajian (Naping, 2013) menyatakan bahwa modal sosial mengandung elemen pokok yang diantaranya hubungan saling percaya (trust), didukung oleh adanya kejujuran (honesty), kewajaran (fairness), sikap egaliter (egalitarianism), toleransi (tolerance) dan kemurahan hati (generosity). hubungan saling percaya bisa tumbuh apabila orang berlaku jujur, dengan kejujuran akan tumbuh pula sikap fair, dan dengan paham egaliter seseorang akan toleran, karena itu ia akan lebih mudah untuk bermurah hati. Sebagaimana dalam (Sumintarsih; Siti Munawaroh; Christriyati Ariani, 2016) mengungkapkan bahwa kejujuran dalam perdagangan merupakan kunci utamanya, sebab akan menumbuhkan sikap saling percaya diantara penjual dengan pembeli sehingga menimbulkan kerja sama yang menguntungkan. Jujur saat mengambil dan membeli barang dari petani atau pemilik jareng sangat penting. Bila kejujuran diterapkan dengan sebagaimana 
mestinya, maka kepercayaan pelanggan dapat mereka peroleh dalam melakukan proses jual beli. Bila ingin membeli barang dagangan dari petani, maka kejujuran harus menjadi pegangan bagi Pajibujibu untuk menarik mereka. Sebab sedikit saja kesalahan yang mereka lakukan saat proses pembelian barang seperti timbangan yang kurang atau pembayaran yang ditunda maka bagi petani biasanya mereka berika efek jerah dengan tidak menjual hasil pertaniannya lagi ke Jibu-jibu yang telah mencurangi mereka. Bahkan pada saat mereka menjual barang dagangannya di pasar Batu Merah dan pasar Mardika, kota Ambon.

Jika pada umumnya proses transaksi jual beli biasanya dapat dipercaya jika ada bukti atau nota transaksi baru bisa dilakukan. Namun berbeda halnya dengan para pedagang Pajibujibu dari Temi atau Tapinalo atau daerah lainnya di pasar Batu Merah dan pasar Mardika. Hanya bermodalkan kesepakatan dalam pembicaraan maka proses transaksi jual beli bisa dilakukan. Berikut pernyataan dari Pajibujibu Nene Elo bahwa "Tidak pakai nota, mereka juga tidak. Dihitung sekian banyaknya barang yang kami berikan, kemudian kami beritahu harga sekian barangnya. Kalau utang sere 20 ikat dengan harga Rp. 7000 totalnya Rp. 140.000. jadi mereka bilang kami pulang dulu, nanti setelah kembali baru dibayar". Karena mereka sangat percaya kepada pedagang dipasar kota. Bagi Pajibujibu kejujuran merupakan hal yang sangat penting dalam proses interaksi dengan pedagang di pasar kota.

Bagi para perempuan Papalele kejujuran merupakan pegangan yang harus dijaga saat mengambil ikan dari Jareng. Karena mereka mengambil ikan untuk dijual tanpa modal awal, sebab hanya keberanian mengambil ikan dari jareng saja itulah modalnya. Ikan diambil dahulu kemudian dijual kedaerah pesisir dan setelah kembali baru dibayar. Kepercayaan penuh dari pemilik ikan diberikan kepada perempuan Papalele, sebab mereka sekampung yang saling mengenal. Jadi tidak ada pemikiran dicurangi soal membayaran ikan yang telah dijual oleh Papalele. Bahkan para perempuan Papalele tidak berniat menipu pemilik ikan karena menurutnya "bila tidak ingin ditipu maka jangan menipu orang lain siapapun itu, termasuk pemilik ikan tersebut" ungkap Papalele Wa Sri. Apapun alasannya yang namanya menipu tidak baik dampaknya bagi diri sendiri atau orang lain.

$>$ Optimis

Menurut Tasmara (2002), individu yang mempunyai etos kerja yang tinggi cenderung suka bekerja keras, ulet, dan pantang menyerah dalam menghadapi setiap tantangan maupun dalam sebuah tekanan. Optimis untuk meraih hasil yang maksimal membutuhkan etos kerja dalam mencapainya. Keyakinan atas apa yang dikerjakan perihal peluang keberhasilannya dalam perdagangan menjadikan para perempuan Pajibujibu dan Papalele pantang menyerah dalam berdagang. Bukan tanpa alasan melakukan itu dalam perdagangan bagi Pajibujibu dan Papalele. Dikarenakan untung yang diperoleh dari hasil penjualan barang dagangan atau ikannya. Namun tidak menutup kemungkinan kadang kerugian 
juga dialaminya. Jika Pajibujibu atau Papalele menginginkan hasil yang maksimal, maka mereka harus bekerja lebih keras lagi.

Optimis merupakan kunci keberhasilan bagi perempuan Pajibujibu dalam bekerja. Tidak ada kata menyerah bagi mereka berjuang untuk kebutuhan keluarganya terutama keperluan anak sekolahnya dan kebutuhan sehari-harinya. Bagi Pajibujibu dan Papalele selama mereka masih bisa melakukannya, maka tidak ada keraguan dalam bertindak. Kadang kesehatan mereka abaikan hanya untuk bisa mendapatkan penghasilan (uang) hari ini bagi keluarganya untuk hari esok. Saat barang dagangan telah Pajibujibu bawa ke pasar kota, kecepatan bertindak menjadi strategi agar barang jualannya dapat segera terjual habis pada hari itu juga atau keesokan harinya. Bila memiliki pelanggan di pasar lebih mudah penjualannya, tapi jika sebaliknya harus jual sendiri seperti yang dikatakan Pajibujibu Ina Udu (wawancara, 16 Juli 2019) “Kadang diopor langsung, bila ada langganannya langganan kami mau beli. Kalau tidak langsung kami jual sendiri di jembatan pasar Batu Merah pada malam sampai pagi hari. Lalu siangnya kami keku (dipikul diatas kepala sebagian barang dagangan) jual di pasar Mardika.

Begitupun dengan Papalele dalam menjual ikannya di daerah pesisir, kecepatan begerak sangat membantu dalam memasarkan ikannya. Ada begitu banyak Papalele yang menjual ikan setiap harinya, bila lambat sedikit dalam bergerak maka mereka dapat mengalami kerugian. Namun bagi Papalele keyakinan atas apa yang dikerjakan mengenai peluang keberhasilannya dalam menjual ikan menjadikan semangat agar tidak pantang menyerah dalam berusaha. Untung dan rugi dalam perdagangan merupakan hal yang biasa terjadi, bahkan saat sudah maksimal melakukan penjualan. Hanya saja harus tetap optimis dengan apa yang dilakukan "Yakin laku semua, tidak ragu" ungkap Papalele Nene Ou.

\section{Tantangan Usaha}

Setiap usaha punya tantangan dan setiap orang punya cara untuk mengatasinya. Begitu pula Pajibujibu dan Papalele dalam mengembangkan usahannya. Ada tiga kendala yang mereka alami yakni akses permodalan, jaringan pemasaran lemah, dan beban rumah tangga.

\section{$>$ Akses Permodalan}

Kajian (Masdupi et al., 2019) menyatakan bahwa akses modal terhadap UMKM dapat meningkatkan pertumbuhan ekonomi. Selain bermanfaat bagi negara agar bisa menstabilkan ekonomi, akses permodalan bisa juga bermanfaat bagi UMKM sebagai sumber pendanaan yang aman dan berkelanjutan. Hanya saja (dalam Kurniawan, 2014) sering kali UMKM mengalami hambatan yaitu tidak mudahnya untuk mendapatkan akses pada sektor keuangan, antara lain masalah sistem dan institusional yang sering terjadi di Indonesia. Berbagai upaya pemerintah Indonesia dalam mengembangkan sektor ril untuk mengatasi hambatan tersebut, termasuk diatur mekanismenya melalui kebijakan Bank Indonesia untuk ketersediaan akses mendapatkan modal bagi UMKM, namun masih saja belum 
berhasil, di antaranya masalah tingkat bunga yang terlalu tinggi dan ketersediaan jaminan yang seringkali tidak tersedia oleh UMKM.

Ketika memulai usaha, seseorang memerlukan akses permodalan. Banyak dan sedikitnya modal berpengaruh terhadap proses dan hasil usaha. Namun tidak demikian bagi pajibujibu dan papalele. Tidak ada pinjaman modal, seperti bantuan dari lembaga perbankan atau pemerintah guna mengembangkan usahanya. Hal itu disebabkan mereka tidaktahuan dimana dan bagaimana meminjam modal usaha, tidak ada jaminan dari mereka untuk syarat pinjaman modal, dan mereka khawatir tidak bisa mengembalikan pinjaman tersebut.

Bagi Pajibujibu, modal awal diperlukan untuk transportasi dan konsumsi selama di pasar kota. Tapi, untuk pembelian barang dikampung, mereka tidak perlu modal karena mereka membawa hasil kebun sendiri seperti kencur dan kunyit. Pada awalnya Pajibujibu membawa hasil kebunnya atau hasil kebun sanak saudaranya yang dibayar setelah kembali dari kota. Setelah beberapa tahun berdagang dan lancar, mereka kemudian membeli barang dari petani di kampung atau tetangga kampung, sebagai tambahan komoditas yang dibawa kekota. Keuntungan dari usaha itu menjadi modal usaha berikutnya. Petani biasanya menjual hasil kebun kepada jibu-jibu yang membayar tunai barang yang diambilnya. Menurut Ina Udu (wawancara, 16 Juli 2019), barang harus langsung lunas setelah diambil dari pemiliknya. Jika tidak maka dia tidak akan mendapat barang tersebut pada saat itu atau pada waktu lain.

Bagi pedagang Wa Nurjana, modal awal bukan yang utama. Perlu kemauan dan keberanian untuk mengambil ikan berapa kontainer dari jareng atau pemiliki ikan. Harganya dapat dibayar setelah ikan terjual. Untung dan rugi menjadi tanggung jawab papalele. Tapi, bila mengalami kerugian besar dalam penjualan, pedagang bernegosiasi dengan pemilik ikan agar menurunkan harga beli yang disepakati pada saat awal pengambilan. Bila kedua belah pihak sudah sepakat, maka harga ikan dibayar setengahnya saja. Namun, bila tidak sepakat, maka Papalele harus membayar penuh sesuai dengan kesepakatan awal.

Bila Pajibujibu tidak pernah mendapatkan penawaran pinjaman modal, maka Papalele pernah mendapatkan tawaran itu. Salah satunya adalah Nene Ou. Dia ditawarkan modal dari dinas perikanan yang langsung datang kerumahnya. Ada lima orang laki-laki kala itu yang mencari orang untuk menawarkan pinjaman. Salah satu dari mereka menawarkan kepadanya "ibu apa bisa kami berikan modal untuk jualan ikan? Untuk persyaratan, kami akan datang lagi untuk menyampaikannya". Dia tentu mau diberikan pinjaman, namun sampai sekarang sudah sepuluh tahun yang bersangkutan tidak pernah datang lagi.

Seorang Papalele, Wa Hamida pernah mendapat tawaran pinjaman modal dari bank dan dia berhasil mendapatkan sejumlah Rp. 25.000.000. Jaminannya berupa kendaraan laut (pentura) dan rumah. Jadi orang dari bank langsung kekampung mengambil gambar pentura, baskom kontainer, jerigen minyak, dan rumah sebagai bukti jaminan pinjaman. Wa Hamida meminjam uang untuk persiapan anaknya 
yang pada saat itu ikut seleksi polisi yang memerlukan banyak dana. Hanya saja di alasan peminjamannya untuk modal papalele, sebab pinjaman diperuntukan untuk modal usaha bagi perkampungan nelayan. Dalam prosesnya, ternyata anaknya tidak lolos seleksi, sehingga uang tersebut digunakan sebagai modal usaha. Wa Hamida mengatakan "daripada uangnya dikembalikan, mendingan diolah untuk keperluan usaha dengan membeli motor bekas yang biasa digunakan menjual disekitar kampung pesisir dan pasar Desa Luhu". Jadi setiap bulannya mereka setor ke Bank Rp. 1.120.000 dari pinjaman yang telah diambil.

Pada kasus Wa Hamida, dia berhasil. Pada pengajuan pinjaman saat itu status suaminya masih kepala dusun, jadi ini bisa menjadi salah satu aksesnya. Sekarang suaminya telah berhenti sebagai kepala dusun dan mulai fokus berdagang bersama istrinya. Sekilas dilihat dari kehidupan mereka cukup mampu untuk bisa mengembalikan pinjaman modal usaha dari beberapa barang kepemilikannya seperti kendaraan laut (pentura) lengkap dengan mesinnya, usaha penjualan bahan bakar kendaraan laut, rumah pribadi, dan papalele sebagai pekerjaannya yang dibantu oleh suaminya dan anak laki-lakinya. Namun dari beberapa barang kepemilikan dan usahanya hanya rumah dan kendaraan laut (pentura) yang menjadi jaminan pinjaman mereka di Bank. Sedangkan, pada kasus Nene Ou tidak berhasil, karena pihak Bank melihat kondisi kehidupan Nene Ou hanya sebagai papalele dan perias pengantin bila jasanya dibutuhkan. Sedangkan suaminya tidak lagi bekerja karena sudah tua, makanya tinggal dirumah menjual minyak tanah saja. Jika hanya rumah sebagai jaminan itu tidak bisa memenuhi persyaratannya untuk meminjam modal usaha di Bank.

$>$ Jaringan usaha lemah

Jaringan atau akses menurut (Lawang, 2005) merupakan sebuah ikatan (orang atau kelompok) yang dihubungkan dengan hubungan sosial dan diikat dengan kepercayaan yang kemudian menjadi kerjasama. Seseorang akan membuka jaringan dengan orang lain jika menurut penilaiannya mempunyai arti baginya, baik secara sosial maupun ekonomi. Pola hubungan tersebut berlangsung dalam prinsip pertukaran sosial. Intinya jika jaringan hubungan itu menguntungkan akan diteruskan, tetapi bila merugikan salah satunya maka hubungan tersebut akan terputus (Homans). Jaringan selalu terjadi antar personal, hanya saja ada yang bertahan atau sebaliknya.

Pada awal usaha pajibujibu, belum ada jaringan di pasar. Jadi mereka datang berdagang di pasar itu ikut dengan saudara atau teman yang lebih dulu berdagang. Hal ini sebagai pengetahuan baginya cara penjualan dan membangun jaringan nantinya. Bagi pajibujibu bertemu langsung dengan pembeli barang (langganan) di pasar sangat penting, sebab berpengaruh terhadap akses jaringan usahanya kedepan. Membutuhkan beberapa bulan atau tahun bagi pajibujibu untuk membangun jaringannya. Setelah jaringan sudah terbangun dengan langganan, lantas mereka mulai mandiri datang berdagang di pasar. Jika dulu 
membangun jaringan penting untuk kelancaran penjualan, maka berbeda dengan sekarang yang tidak lagi mengutamakan jaringan di pasar.

Menurut Nene Elo kondisi usaha sekarang berbeda dengan dahulu, dalam hal pengoperan barang. Hubungan antara pajibujibu dan pelanggan di pasar kota berbeda. Dahulu, semua barang yang dibawa dari kampung langsung diberikan kepada pelanggan, sehingga dia tidak menjual pada malam atau siang hari. Ketika datang di pasar Batu Merah membawa barang, mereka selalu disambut baik oleh pelanggannya. Ketika datang di kios (tempat dagang pelanggan), pertanyaan awal yang mereka terima adalah mau makan apa? Bukan ditanya soal jenis barang yang dibawa! Karena itulah pajibujibu senang menjalin hubungan jual beli dengan yang bersangkutan. Mereka tidak khawatir meninggalkan harga barang yang belum diambil dari pelanggan, kendati pun lebih seminggu, karena telah terbangun sikap saling percaya diantara mereka. Dalam konteks ini, kepercayaan dan kejujuran sangat penting untuk menjaga kontinuitas usahanya.

Idealnya membangun jaringan pemasaran sangat penting untuk memperlancar penjualan barang dan mengembangan usaha. Tetapi kenyataanya, bagi pajibujibu perdagangan sekarang membangun jaringan tidak terlalu penting. Sebab dalam proses penjualannya, pengambil barang yang langsung membayar lunas itu menjadi prioritas utama penjualannya. Hal itu dilakukan mengingat modalnya yang minim dan tidak ada cadangan modal bila harga barang dagangan pajibujibu ditunda pembayarannya. Sedangkan bagi pedagang papalele pengopor membangun jaringan itu penting untuk kelancaran penjualannya. Berbeda dengan pedagang papalele pengecer yang tidak memerlukan jaringan usaha, sebab ikannya selalu dijual langsung dengan berkeliling disetiap kampung yang didatangi.

Perbandingan usaha dahulu dan sekarang berbeda. Jaringan pemasaran atau langganan tidak lagi menjadi prioritas bagi pajibujibu yang datang di pasar Batu Merah. Ina Udu mengatakan bahwa sekarang mereka lebih banyak menjualnya sendiri pada malam hari di jembatan pasar Batu Merah, di depan jalan utama, dan pada siang hari dijajakan di Pasar Mardika. Dengan metode ini (pertama), mereka langsung memperoleh harga barangnya.

Metode lain, mereka mengopernya kepada pelanggan di pasar. Cara ini tidak menyulitkan Pajibujibu untuk menjual barang dalam tempo yang lama, namun kendalanya ketika pembayaran harga barang yang kerap ditunda-tunda. Menurut Nene Elo, bahwa kedatangan mereka di pasar dicari oleh pembeli atau pelanggan bila jenis barang yang dibawa memang sedang laku dipasaran, sebaliknya, mereka harus berusaha sendiri dengan metode pertama.

Bagi papalele pemborong, seperti $\mathrm{Wa} \mathrm{Abu}$, jaringan usaha sangat penting untuk memperlancar penjualan ikan. Komunikasi dengan penadah di pasar pelabuhan Hitu sangat baik, karena sebelum membawa ikan dari kampung terlebih dahulu mereka berkomunikasi mengenai berapa banyak ikan yang bisa dibawa untuk dijual kepada penadah. Setelah saling kontak, baru Wa Abu mencari diantara empat jareng yang menjadi tempat untuk mengambil ikan. Bila satu jareng dapat 
memenuhi semua permintaan, maka itu sudah cukup untuk menuju pelabuhan Hitu. Tapi, jika tidak mencukupi, maka dia harus mencari jareng yang lain. Jam enam pagi, mereka menuju jareng yang masih di laut dengan menggunakan kendaraan pentura, sebab ikan dibeli di laut, bukannya di darat. Berbeda dengan papalele pengecer, yang menganggap jaringan usaha kurang penting. Sebab ikan yang mereka bawa selalu dijual langsung secara eceran sampai habis. Penjualan eceran lebih menguntungkan mereka, bila dibandingkan pengoperan langsung kepada penadah.

\section{Penutup}

Apa yang dikemukakan Weber (2006) bahwa faktor agama sebagai sumber lahirnya etos kerja, pada konteks studi ini tidak terbukti. Etos kerja perempuan Buton lahir karena tantangan alam, peluang usaha, dan kondisi ekonomi sehingga harus punya semangat kerja untuk menjawab tantangan tersebut. Serta nilai budaya sabangka asarope menjadi penguat untuk satu tujuan dalam melangkah. Pandangan Coleman tentang pilihan rasional lebih relevan, bahwa etos kerja lahir karena mereka berada pada situasi yang membuat harus memilih diantara pekerjaan yang lebih sesuai kebutuhan mereka. Memilih menjadi pedagang Pajibujibu atau Papalele adalah pilihan rasional mereka. Mengangkses pasar ketika terjadi kerusuhan pasca konflik sebetulnya punya resiko. Tapi di sana juga ada peluang usaha yang ditinggalkan pedagang sebelumnya, dan itu membuat mereka memilih mengambil peluang tersebut. Bagi mereka, itulah pilihan yang paling rasional untuk mempertahankan hidup. Dalam perjalanannya, etos kerja mereka bisa terus bertahan sampai sekarang karena dengan empat aspek yang dimiliki. Aspek kesadaran atas situasi yang dihadapi dan menemukan peluang untuk mengatasi situasinya. Aspek kesungguhan dan mandiri dalam melakukan aktifitas perdagangannya. Aspek kejujuran saat melakukan penjualan dan pengambilan barang dagangan dari pemilikinya. Aspek optimis untuk meraih hasil dari pekerjaan yang dilakukannya. Aktifitas perdagangan ini juga memiliki kendala yang dihadapi dalam prakteknya seperti akses permodalan dalam memperbesar usahanya dan jaringan usaha lemah sehingga perdagangannya hanya sebatas penjualan di pasar kota saja dan dibagian pesisir. Namun ketiga hal itu tidak membuat Pajibujibu dan Papalele serta merta berhenti berdagang.

\section{Ucapan Terimakasih}

Artikel ini merupakan bagian dari tesis saya, "Etos Kerja Perempuan Pedagang (Studi Kasus Perempuan Buton Sebagai Pajibujibu dan Papalele di Pesisir Barat Pulau Seram, Kabupaten Seram Bagian Barat, Maluku)", pada program pascasarjana Departemen Sosiologi, Universitas Hasanuddin. Saya ucapkan terimakasih kepada Pembimbing tesis yang telah memberikan banyak masukan dalam penulisan tesis, dan khususnya pada artikel ini.

\section{Conflicts of interest}

Penulis menyatakan tidak ada konflik kepentingan. 


\section{Daftar Pustaka}

Abdullah, T. (1986). Agama, Etos Kerja dan Perkembangan Ekonomi. LP3ES.

Anoraga, P. (2001). Psikologi Kerja, Edisi baru: Jakarta. Rineka Cipta.

Bolu, W. M. E. V. (2019). BAWINE: KARYA TARI YANG TERINSPIRASI PADA CITRA PEREMPUAN BUTON. JOGED: Jurnal Seni Tari, 13(2), 142-157.

Butar, C. B. (2020). Statistik Daerah Provinsi Maluku. BPS Provinsi Maluku.

Hamid, A. R. (2011). Orang Buton: Suku Bangsa Bahari Indonesia. Ombak.

Hamid, A. R. (2016). Binongko people's life in Coral Island. Wacana, 17(1), 19-37. https:// doi.org/10.17510/wacana.v17i1.451

Hamid, A. R. (2015). Membaca (Kembali) Identitas Binongko: Perspektif Sejarah. International Conference on Language, Culture and Society (ICLCS), 37-45.

Kasman Renyaan. (2016). Budaya Maritim Migran Buton di Pantai Barat Seram 1942-2002. Universitas Negeri Makassar.

Lawang, R. M. Z. (2005). Kapital sosial dalam perspektif sosiologik: Suatu pengantar. Fakultas Ilmu Sosial dan Ilmu Politik, Universitas Indonesia (FISIP UI) Press.

Masdupi, E., Rasyid, R., \& Rahmiati, R. (2019). Pengelolaan Keuangan dan Akses Permodalan Sebagai Solusi Dalam Pengembangan Usaha Kecil Sulaman di Nagari Panampuang Kabupaten Agam Sumatera Barat. Jurnal Penerapan IPTEKS, 1(2), 50-57.

Naping, H. N. (2013). Modal Sosial Sebagai Strategi Pengentasan Kemiskinan Secara Mandiri Pada Desa Nelayan di Sulawesi Selatan dan Sulawesi Barat. SOCIUS: Jurnal Sosiologi, 1-14.

Ritzer, G., \& Goodman, D. J. (2003). Teori Sosiologi Modern. Prenada Media.

SUKARDEWI, D. N., Dantes, N., \& Natajaya, I. N. (2013). Kontribusi adversity quotient (aq), etos kerja, dan budaya organisasi terhadap kinerja guru sma negeri di Kota Amlapura. Jurnal Administrasi Pendidikan Indonesia, 4(1).

Sumintarsih; Siti Munawaroh; Christriyati Ariani. (2016). Gusjigang: Etos Kerja Dan Perilaku Ekonomi Pedagang Kudus. http://opac.lib.ugm.ac.id/index.php? mod=book_detail\&sub=BookDetail\&act=view\&typ=htmlext\&buku_id=750892\& unit_id=1

Tahara, T. (2016). Pelayaran Tradisional Orang Buton dan Kebijakan Poros Maritim Indonesia. Jurnal Masyarakat Dan Budaya, 18(3), 353-368.

Talakua, Y. (2018). MIGRASI ORANG BUTON KE AMBON (Studi Pada Orang Buton Di Dusun Telaga Pangi Negeri Rumahtiga KecamatanTeluk Ambon, Kota Ambon). Dialektika Masyarakat: Jurnal Sosiologi, 2(2), 15-34.

Tasmara, T. (2002). Membudayakan etos kerja Islami. Gema Insani.

Udu, S. (2009). Perempuan Dalam Kabanti: Tinjauan Sosiofeminis. Diandra.

Udu, S. (2017). Wowine Dalam Kebudayaan Maritim Wakatobi Buton: Analisis Pierre Bourdieu. SASDAYA: Gadjah Mada Journal of Humanities, 2(1), 267-282.

Weber, M. (2006). Etika Protestan dan Spirit Kapitalisme. Pustaka Pelajar.

Weber, M. (2009). Sosiologi. Pustaka Pelajar.

Zuhdi, S. (2014). Nasionalisme, Laut dan Sejarah. Komunitas Bambu.

Zuhdi, S. Didik Pradjoko, Setiawan, A., \& Noor Fatia Lastika Sari. (2019). Orang Buton Dalam Diaspora Nusantara dan Integrasi Bangsa. Wedatama Widya Sastra. 